\title{
Calcium Transients in Infant Human Atrial Myocytes
}

\author{
MARY B. WAGNER, YANGGAN WANG, RAJIV KUMAR, SRINIVAS M. TIPPARAJU, AND \\ RONALD W. JOYNER
}

The Todd Franklin Cardiac Research Laboratory, The Sibley Children's Heart Center, Department of Pediatrics, Emory University School of Medicine, Atlanta, GA 30322

\begin{tabular}{|c|c|}
\hline \multicolumn{2}{|c|}{ ABSTRACT } \\
\hline $\begin{array}{l}\text { Isolated infant human atrial cells have a slower early repo- } \\
\text { larization than adult human atrial cells. In addition, from room } \\
\text { temperature voltage-clamp studies, infant cells have lower basal } \\
\text { L-type calcium currents than adult cells. We hypothesized that } \\
\text { the slower repolarization increases the calcium transient of infant } \\
\text { human atrial cells. Atrial myocytes were enzymatically dissoci- } \\
\text { ated from biopsies of human right atrial appendages of infant } \\
\text { ( } 3-8 \mathrm{mo}) \text { patients who were undergoing open-heart surgery. } \\
\text { Intracellular calcium transients were measured with fluorescence } \\
\text { microscopy with application of either square waves or action } \\
\text { potential waveforms at physiologic temperature. After repetitive } \\
\text { application }(1 \mathrm{~Hz}) \text { of } 100-\mathrm{ms} \text { duration conditioning depolariza- } \\
\text { tions to } 10 \mathrm{mV} \text { (from }-80 \mathrm{mV}) \text {, a test pulse of varying duration } \\
\text { ( } \Delta \mathrm{T} \text {; } 2-100 \mathrm{~ms}) \text { produced smaller transients (expressed as per- } \\
\text { centage of the last conditioning pulse) at shorter durations ( } 33 \pm \\
7 \% \text { for } \Delta \mathrm{T}=2 \mathrm{~ms}, 80 \pm 4 \% \text { for } \Delta \mathrm{T}=25 \mathrm{~ms} \text { ). With repetitive } \\
\text { application of either adult or infant prerecorded action potentials } \\
\text { to infant cells, the cells had a decreased calcium transient with } \\
\text { the adult action potential }\left(\mathrm{F} / \mathrm{F}_{\mathrm{O}} 2.2 \pm 0.4 \text { for infant action }\right.\end{array}$ & $\begin{array}{l}\text { potential versus } 1.6 \pm 0.2 \text { for adult action potential; } n=7 ; p< \\
0.05 \text { ). The delayed early repolarization of infant cells alters the } \\
\mathrm{Ca}^{2+} \text { transient, which may compensate for the lower availability } \\
\text { of basal calcium current in infant cells. The steep relationship } \\
\text { that we have demonstrated between test-pulse duration and the } \\
\text { calcium transient suggests that modulation of the early repolar- } \\
\text { ization phase of the action potential may be of great significance } \\
\text { in modulating excitation-contraction coupling. (Pediatr Res 57: } \\
\mathbf{2 8 - 3 4 , 2 0 0 5 )}\end{array}$ \\
\hline
\end{tabular}

The time course and amplitude of the calcium current, which leads via sarcoplasmic reticulum (SR) calcium release to the calcium transient of cardiac cells, depend not only on the properties of the calcium channel but also on the action potential waveform. Changes in the action potential repolarization rate have been shown to have effects to either increase or decrease the net calcium current and the release of calcium from the SR (1-3). In our recent work comparing action potential waveforms and the amplitude and time course of transient outward current in isolated infant versus adult human

Received November 26, 2003. accepted June 2, 2004.

Correspondence: Ronald W. Joyner, M.D., Department of Pediatrics, Emory University School of Medicine, 2040 Ridgewood Drive, Atlanta, GA 30322; e-mail: rjoyner@cellbio.emory.edu

This work was partially supported by National Institutes of Health Grant HL56787 (R.K.), a Scientist Development Grant from the American Heart Association, a Biomedical Engineering Research Grant from the Whitaker Foundation (M.B.W.), National Institutes of Health Grant HL22475 (R.W.J.), The Sibley Children's Heart Center, and the Emory Egleston Children's Research Center.

DOI: 10.1203/01.PDR.0000148066.34743.10 atrial cells (4), we showed 1) that infant atrial cells had transient outward current that inactivated much more rapidly than adult atrial cells and 2) that infant cells had a much slower early repolarization phase [consistent with previous work on atrial strips (5)]. The time for $30 \%$ repolarization from the peak of the action potential $\left(\mathrm{APD}_{30}\right)$ was $24.4 \pm 11.4 \mathrm{~ms}$ for infant atrial cells compared with only $3.6 \pm 0.4 \mathrm{~ms}$ for adult atrial cells. We have also shown that infant cells have a lower basal amplitude of calcium current than do either young adult or older adult atrial cells (6), with peak L-type calcium current $\left(\mathrm{I}_{\mathrm{Ca}}\right)$ from voltage steps to $10 \mathrm{mV}$ at room temperature being $1.2 \pm 0.1 \mathrm{pA} / \mathrm{pF}$ for infant cells and $2.6 \pm 0.3 \mathrm{pA} / \mathrm{pF}$ for adult cells.

The lower $\mathrm{I}_{\mathrm{Ca}}$ (from square wave voltage-clamp studies) and the prolonged early repolarization phase of the infant atrial cells (from current clamp single-cell studies) may be related in a functional sense if the prolongation of the early repolarization served to increase the calcium entry and thus the intracellular calcium transient in infant atrial cells compared with the faster 
repolarization rate of the adult action potential waveform. We used square wave voltage-clamp depolarizations of varying duration applied to infant atrial cells to determine the relationship between pulse duration and the amplitude of the calcium transient. We also applied either adult or infant recorded action potential waveforms to isolated infant atrial cells to test more directly the hypothesis that the slowed early repolarization of the action potential of the infant atrial cells increases the calcium transients for infant cells compared with the calcium transients that would have occurred if infant cells had the same action potential waveform as adult cells.

\section{METHODS}

Patients. Biopsies from right atrial appendage were obtained at the time of initiation of cardiopulmonary bypass from infant patients (age 3-8 mo; $n=4$; Table 1). All patients were in normal sinus rhythm at the time of surgery with no documented history of previous atrial fibrillation or atrial dilation. The characteristics of the patients are given in Table 1. The study protocols for using infant atrial biopsies were approved by the Emory University Human Investigation Committee and by Children's Healthcare of Atlanta. The investigation conforms with the principles outlined in the Declaration of Helsinki.

Preparation of isolated cells. As we have described previously (4), atrial tissue obtained at the time of surgery was placed in oxygenated $\mathrm{Ca}^{2+}$-free Krebs-Ringer (KR) solution (plus $30 \mathrm{mM}$ of 2,3-butanedione monoxime $(\mathrm{BDM}))$ and transported to the laboratory within $5 \mathrm{~min}$ after excision and cut into small chunks. Tissue chunks were stirred in oxygenated $\mathrm{Ca}^{2+}$-free $\mathrm{KR}$ (without $\mathrm{BDM}$ ) solution at $34-36^{\circ} \mathrm{C}$. After $10 \mathrm{~min}, \mathrm{Ca}^{2+}$-free $\mathrm{KR}$ was supplemented with collagenase $(1 \mathrm{mg} / \mathrm{mL}$ type IV; Sigma Chemical Co., St. Louis, MO) and protease ( $0.4 \mathrm{mg} / \mathrm{mL}$ type XXIV; Sigma Chemical Co.). After digestion, tissue chunks were triturated and the supernatant was tested every 15 min under the microscope. Cells were then separated by centrifugation and resuspended in storage solution that contained $1 \mathrm{mg} / \mathrm{mL}$ of BSA and kept in a refrigerator until used.

Fluorescent measurements with confocal laser scanning microscopy. We monitored intracellular $\mathrm{Ca}^{2+}$ during different voltage waveforms in infant human atrial cells at physiologic temperature $\left(37^{\circ} \mathrm{C}\right)$ using $75 \mu \mathrm{M}$ of Fluo-4, a fluorescent $\mathrm{Ca}^{2+}$ indicator dye (pentapotassium salt; Molecular Probes, Eugene, OR) in the pipette solution (2). We used the action potential clamp with prerecorded action potentials (at physiologic temperature) that we previously published from adult and infant human atrial cells (4) applied as repetitive $(1 \mathrm{~Hz})$ voltage-clamp waveforms to isolated infant atrial cells. We also applied a conditioning train of $8100 \mathrm{~ms}$ square waves from $-80 \mathrm{mV}$ to $0 \mathrm{mV}$ followed by a pulse of varying duration to determine the dependence of the $\mathrm{Ca}^{2+}$ transient on pulse duration. The application of both the action potential waveforms and the square waves was done in random order and repeated at least twice to ensure that the calcium transient was stable. Cells without stable calcium transients were excluded from the analysis.

The fluorescent imaging was performed with a confocal laser scanning microscope (OZ; Noran Instruments, Inc., Madison, WI) coupled to an inverted microscope (IX-70, Olympus, Melville, NY) equipped with a $\times 60$ water immersion objective (UPlanApo, numerical aperture $=1.2$; Olympus). Fluo-4 fluorescence was excited with the 488-nm line of a krypton-argon laser. Emitted fluorescence is measured at wavelengths $>500 \mathrm{~nm}$. Images were collected by an $\mathrm{O}_{2}$ workstation (Silicon Graphics, Mountain View, CA) using Noran InterVision software. Images were acquired at a rate of $240 \mathrm{images} / \mathrm{s}$

Table 1. Patient characteristics

\begin{tabular}{ccll}
\hline Patient & Age $(\mathrm{mo})$ & \multicolumn{1}{c}{ Sex } & Diagnosis \\
\hline 1 & 5 & Female & TOF \\
2 & 6 & Female & TOF \\
3 & 3 & Male & ASD/VSD \\
4 & 8 & Female & ASD/VSD \\
\hline
\end{tabular}

ASD, atrial septal defect; VSD, ventricular septal defect; TOF, tetralogy of Fallot. yielding a total image area of $1255 \mu \mathrm{m}^{2}$. Data were analyzed using a modified version of ImageJ (National Institutes of Health, Bethesda, MD). For each image, a region of interest was drawn within the cell boundaries and the average intensity of the fluorescence within that region was calculated. Data are plotted as the ratio $\mathrm{F} / \mathrm{F}_{0}$, where $\mathrm{F}$ is the average fluorescence intensity at a given time over the region of interest and $\mathrm{F}_{0}$ is the resting value of fluorescence found by averaging $20 \mathrm{~ms}$ of data $40 \mathrm{~ms}$ before application of the action potential or square wave waveform to the cell.

Solutions and Drugs. The compositions of standard solutions used are as follows (in mM). $\mathrm{Ca}^{2+}$-free KR solution: $35 \mathrm{NaCl}, 4.75 \mathrm{KCl}, 1.2 \mathrm{KH}_{2} \mathrm{PO}_{4}, 16$ $\mathrm{Na}_{2} \mathrm{HPO}_{4}, 134$ sucrose, $25 \mathrm{NaHCO}_{3}, 10$ glucose, and 10 HEPES (pH 7.4) with $\mathrm{NaOH}$. Storage solution: $100 \mathrm{~K}$-glutamate, $25 \mathrm{KCl}, 10 \mathrm{KH}_{2} \mathrm{PO}_{4}, 0.5$ EGTA, 1 $\mathrm{MgSO}_{4}, 20$ taurine, 10 glucose, and HEPES 5 (pH 7.2) with KOH, $\mathrm{I}_{\mathrm{Ca}}$. Pipette solution for action potential clamp with fluorescence measurements: $135 \mathrm{KCl}$, $5 \mathrm{Na}_{2} \mathrm{CrPh}, 5 \mathrm{MgATP}, 10$ HEPES, and 0.075 Fluo- 4 pentapotassium salt ( $\mathrm{pH}$ 7.2) with $\mathrm{KOH}$. External solution for action potential clamp with fluorescence measurements: $148.8 \mathrm{NaCl}, 4 \mathrm{KCl}, 1.8 \mathrm{CaCl}_{2}, 0.53 \mathrm{MgCl}_{2}, 0.33 \mathrm{NaH}_{2} \mathrm{PO}_{4}, 5$ HEPES, and 5 glucose $(\mathrm{pH} 7.4)$ with $\mathrm{NaOH}$. Modifications to these solutions are described below for specific protocols.

Statistics. All values are presented as mean \pm SEM. Comparison of measured parameters was done using a paired $t$ test. A $p<0.05$ was defined as significant.

\section{RESULTS}

Ca transients with variable duration square wave pulses. We applied square wave voltage-clamp pulses of varying duration at physiologic temperature to infant human atrial cells to determine whether longer duration pulses would enhance the $\mathrm{Ca}^{2+}$ transient. Using a holding potential of $-80 \mathrm{mV}$, we applied eight conditioning pulses (to $10 \mathrm{mV}, 100-\mathrm{ms}$ duration) at a frequency of $1 \mathrm{~Hz}$ followed by a test pulse to $10 \mathrm{mV}$ of varying durations $(2,5,10,25,50$, and $100 \mathrm{~ms})$. The results from one infant human atrial cell are shown in Fig. 1. Images were taken with a time step of $4 \mathrm{~ms}$. The voltage waveforms

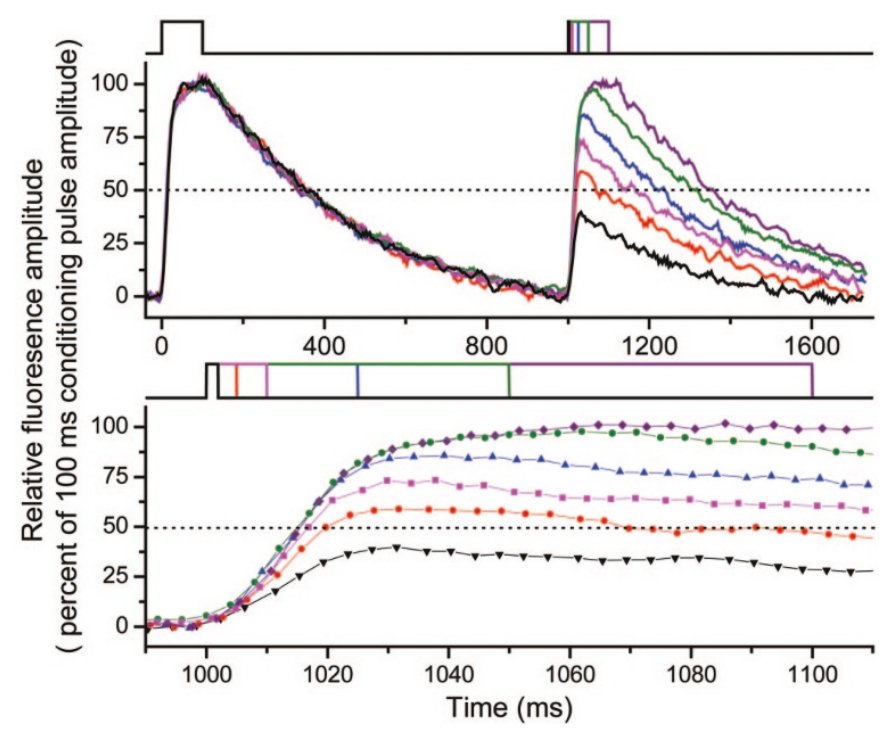

Figure 1. (Top) Time course of relative fluorescence for application of square wave depolarizations from $-80 \mathrm{mV}$ to $10 \mathrm{mV}$, with eight depolarizations of 100-ms duration (at $1 \mathrm{~Hz}$ ) followed by a depolarization of varying durations of $2,5,10,25,50$, or $100 \mathrm{~ms}$ indicated by different colors, with the shortest test depolarization in black. Fluorescence for each trace is normalized to the peak value produced by the last of the conditioning 100-ms duration depolarizations. (Bottom) Fluorescence responses to the test pulses at a faster time base. Individual symbols correspond to the fluorescence measurements at 4-ms intervals. 
are superimposed above each part of the figure. The fluorescence for the voltage step of varying duration was normalized to the calcium transient recorded during the last conditioning pulse so that the minimum fluorescence was set to $0 \%$ and the maximum was $100 \%$. Thus, the response to the test pulse (applied at time $1000 \mathrm{~ms}$ ) is reported in terms of the percentage of its conditioning pulse (applied at $0 \mathrm{~ms}$ ), so each record served as its own control. We completed this protocol in seven infant cells. Figure 1, top, shows the data including, for each trace, the last of the 100-ms duration conditioning pulses and the response to the test pulse. The shortest duration test pulse (2-ms duration; black line) resulted in a $\mathrm{Ca}^{2+}$ transient less than half that of the conditioning pulse, and the relative fluorescence amplitude increased progressively as the duration of the test pulse was increased. Figure 1, bottom, shows the initial portion of the responses to the test pulses, with the symbols indicating specific fluorescence measurements. The fluorescence begins to rise within $4 \mathrm{~ms}$ of the pulse application and nearly reaches a peak within $30 \mathrm{~ms}$. Note that the rate of rise of the fluorescence is slower for the very short-duration test pulses and then becomes nearly identical for test pulses longer than $10 \mathrm{~ms}$.

The mean relative amplitudes of the calcium transients versus the duration of the test pulse is shown in Fig. 2. The calcium transient amplitude (compared with the preceding 100 -ms duration conditioning pulse) rises from $33 \pm 7 \%$ for a test-pulse duration of $2 \mathrm{~ms}$ and shows a steep relationship with test-pulse duration, with a value of $80 \pm 4 \%$ with a test-pulse duration of $25 \mathrm{~ms}$. On this figure, we have indicated our previously reported values (4) for the $\mathrm{APD}_{30}$ of infant atrial cells $(24.4 \mathrm{~ms})$ and for adult atrial cells $(3.6 \mathrm{~ms})$, at the same physiologic temperature, as vertical dashed lines. To the extent that the action potentials could be approximated by square wave waveforms, the intersections of the dashed lines with the measured relationship (at 40 and $80 \%$ of the maximum tran-

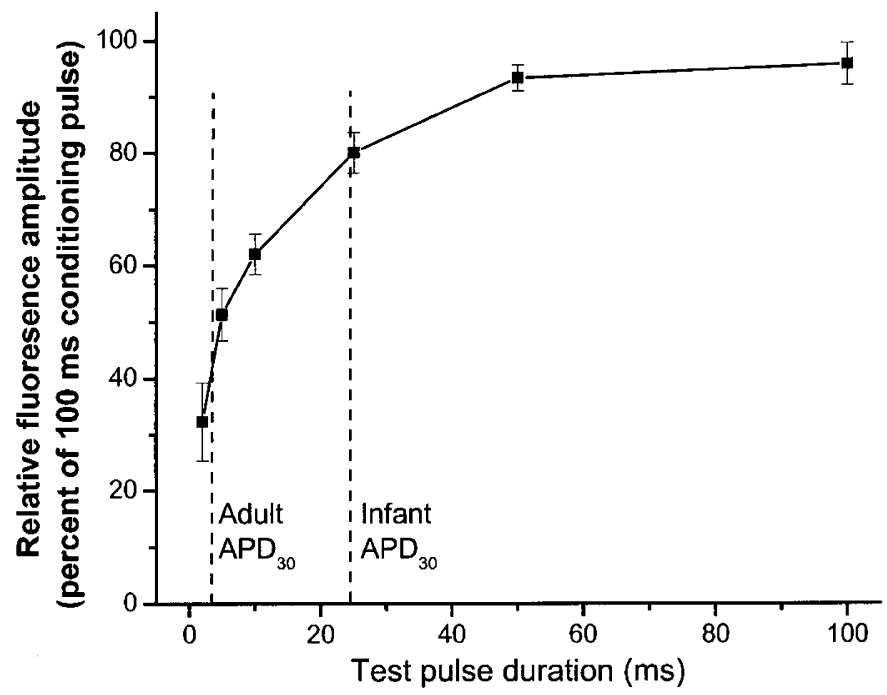

Figure 2. Relative fluorescence measurements (as in Fig. 1) for test-pulse durations from 2 to $100 \mathrm{~ms}$ with mean and SEM plotted for seven infant atrial cells plotted as a function of the test-pulse duration. The vertical dashed lines are placed to indicate the values that we previously reported for the $\mathrm{APD}_{30}$ of isolated adult and infant human atrial cells (4). sient for the adult $\mathrm{APD}_{30}$ compared with the infant $\mathrm{APD}_{30}$ ) suggests that the longer $\mathrm{APD}_{30}$ of the infant action potentials might produce twice the calcium transient in an infant cell as the adult action potentials for the same cells.

Calcium transients with action potential clamp. We monitored $\mathrm{Ca}^{2+}$ transients of infant atrial cells from the same patients in response to changes in the action potential waveform using the same confocal laser scanning fluorescence microscopy in voltage-clamp mode at physiologic temperature. We applied prerecorded action potentials from adult and infant human atrial cells [as illustrated in our recent publication (4)] as voltage-clamp waveforms (Fig. 3) to monitor $\mathrm{Ca}^{2+}$ transients in these infant human atrial cells. For each infant cell, we used trains of eight action potential waveforms at $1-\mathrm{Hz}$ frequency and compared the results for each cell for the application of a train of adult action potentials versus a train of infant action potentials. The eighth application of the adult or infant action potential is superimposed in Fig. 3, top. The simultaneously recorded calcium transients are plotted as $\mathrm{F} / \mathrm{F}_{0}$ (Fig. 3,
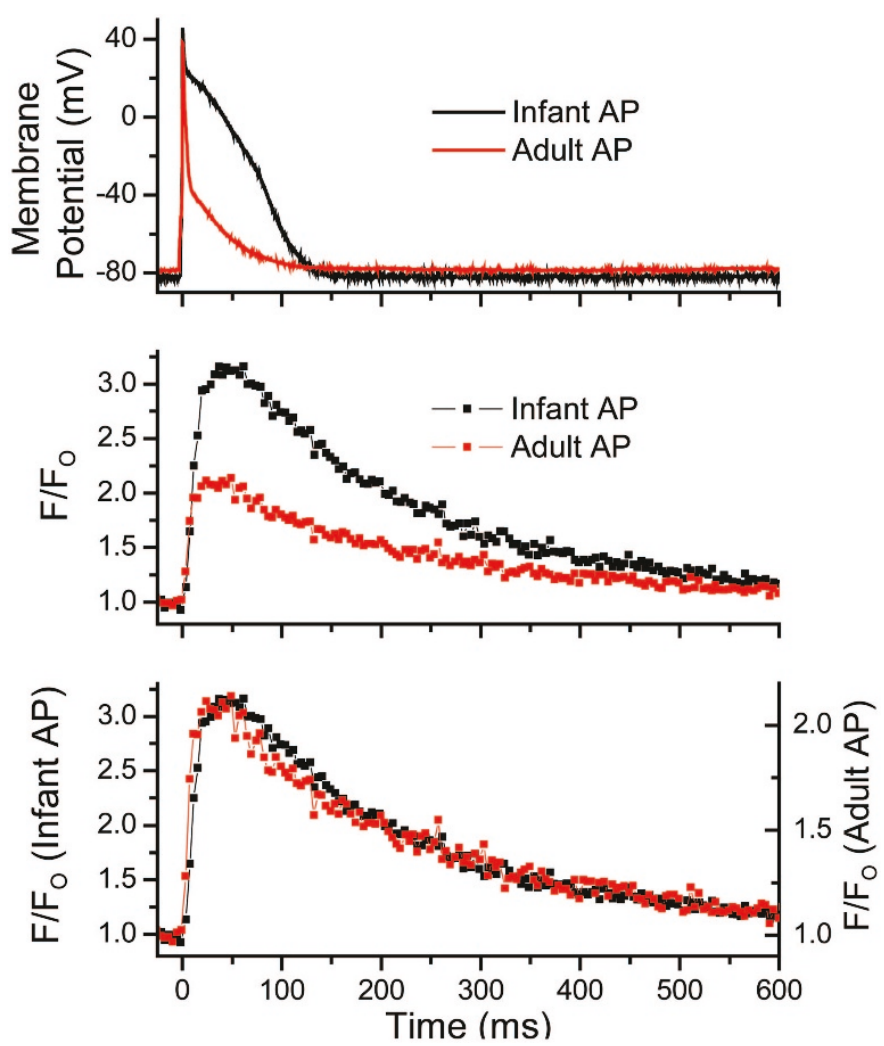

Figure 3. Application of the action potential clamp technique to an isolated infant atrial cell. The action potential waveforms were previously recorded action potentials at physiologic temperature, as we previously published (4), from an infant and an adult human atrial cell. The action potential waveforms were applied in a train at $1 \mathrm{~Hz}$ with the data shown as the eighth action potential in a train of infant or adult action potential waveforms in the voltage-clamp mode. (Top) Membrane potential for this cell with the adult action potential (red) or the infant action potential (black). (Middle) Simultaneously recorded fluorescence signal (240 frames/s) with the fluorescence averaged over the cell area for each time point and normalized to $F_{0}$, the averaged fluorescence for $20 \mathrm{~ms}$ before the action potential upstroke. (Bottom) Data of the middle replotted on separate vertical scales (left scale for the infant action potential waveform, right scale for the adult action potential waveform) to make the peaks of the curves the same. 
middle), where $\mathrm{F}_{0}$ was the average fluorescence for $20 \mathrm{~ms}$ before the application of the action potential waveform. The calcium transients began to rise very quickly after the action potential depolarization and reached peak values within $\sim 20 \mathrm{~ms}$ for both of the action potential waveforms. However, the peak value obtained for this infant atrial cell with the infant action potential (black trace and symbols) was much larger than the peak obtained for the same infant cell with the adult action potential (red trace and symbols). The calcium transients for the two different action potential waveforms are plotted in Fig. 3 bottom, with two different vertical scales to make the peak values coincide on the graph (left scale for the infant action potential waveform, right scale for the adult action potential waveform). The transients began to decrease during the repolarization of the action potentials and then followed a very similar time course for both infant and adult action potentials.

The action potentials and $\mathrm{Ca}^{2+}$ transients of Fig. 3 are replotted in Fig. 4, top and middle, at a faster time scale. Note that the $\mathrm{Ca}^{2+}$ transient increases at the same rate for the first 12 ms (three fluorescence data points) after action potential depolarization with either of the action potential waveforms. After $12 \mathrm{~ms}$, the adult action potential waveform has significantly repolarized, whereas the infant action potential waveform is still at a high plateau level. In response to the infant action potential waveform, the calcium transient continues to increase for another $12 \mathrm{~ms}$ to obtain the higher peak of calcium transient. Figure 4, bottom, shows the confocal images corresponding to calcium transients at successive 4-ms intervals starting
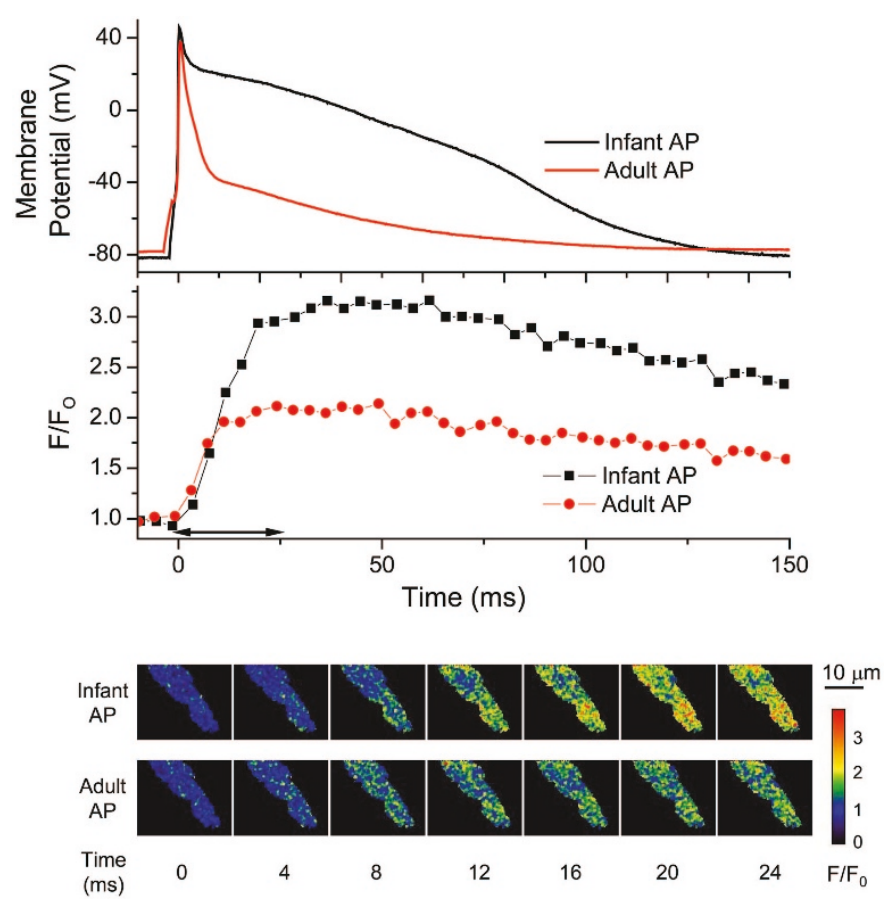

Figure 4. (Top and middle) Replots Fig. 3, top and middle, at a faster scale to show the rising phase and repolarization of the action potential time courses (top) and the rising phases of the calcium transients. (Bottom) Actual fluorescence images acquired from this cell at 4-ms intervals, during the period indicated by the horizontal arrow in the middle, when we applied either the infant action potential waveform (top row) or the adult action potential waveform (bottom row). The pixels range from blue (low fluorescence) to red (high fluorescence). just before depolarization occurs over the time period of $24 \mathrm{~ms}$, indicated by the horizontal arrow in Fig. 4, middle. For both action potential waveforms, there is an increase in fluorescence that is apparent even within $4 \mathrm{~ms}$ after the action potential upstroke. The fluorescence progressively increases with time for each action potential waveform up to $12 \mathrm{~ms}$ and then continues to increase only for the infant action potential waveform up to the 24-ms time point.

Figure 5 shows a summary of the results for application of either the adult or the infant action potential waveform to seven infant atrial cells. The peak $\mathrm{Ca}^{2+}$ transient (peak of $\mathrm{F} / \mathrm{F}_{0}$ ) in response to the infant action potential waveform was significantly larger than the peak $\mathrm{Ca}^{2+}$ transient for the same cells in response to the adult action potential waveform $(2.2 \pm 0.4$ versus $1.6 \pm 0.2 ; p<0.05)$, an average increase of $49 \pm 4 \%$. The half maximal decay time was not significantly different for the two waveforms $(230 \pm 14 \mathrm{~ms}$ for the infant action potential versus $204 \pm 15 \mathrm{~ms}$ for the adult action potential), showing that the decay of the calcium transient was unaffected by the shape of the stimulating waveform.

\section{DISCUSSION}

In this study, we have shown that the amplitude and the duration of the calcium transient in human infant atrial cells has a steep dependence on the duration of the membrane depolarization that initiates the transient. This phenomenon has also been shown in ventricular myocytes from several species (7-10). Cannell et al. (8) showed that short-duration pulses $(<40 \mathrm{~ms})$ abbreviated the calcium transients of rat ventricular myocytes. They attributed this abbreviation possibly to voltage dependence of the SR release. Cleeman and Morad (9) showed that this abbreviation occurred whether the pulse duration was interrupted by repolarization or by depolarization to $100 \mathrm{mV}$, suggesting that the dependence of the $\mathrm{Ca}^{2+}$ transient amplitude on duration was modulated by $\mathrm{Ca}^{2+}$ influx through $\mathrm{I}_{\mathrm{Ca}}$. Bers et
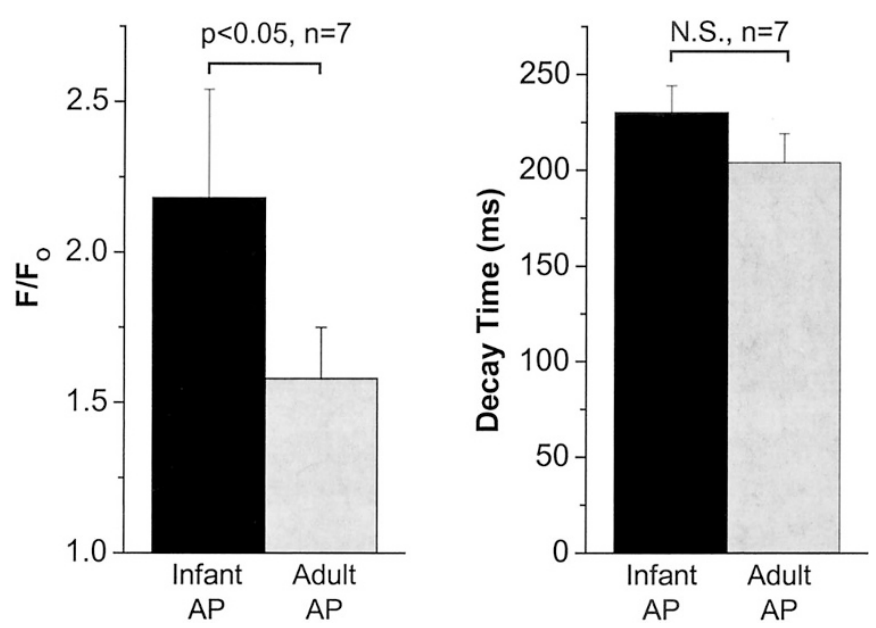

Figure 5. Comparison of the peak fluorescence and the decay time for fluorescence for seven infant cells to which we applied the adult or infant prerecorded action potentials (as in Figs. 3 and 4), showing mean \pm SEM. Compared with the infant action potential waveform, the adult action potential waveform produced significantly less peak fluorescence without altering the decay time of fluorescence for these infant cells. 
al. (7) investigated whether extrusion of $\mathrm{Ca}^{2+}$ by the sodiumcalcium exchanger could account for the abbreviation of the $\mathrm{Ca}^{2+}$ transient with short-duration pulses and found that block of sodium-calcium exchanger did not alter pulse duration dependence of the $\mathrm{Ca}^{2+}$ transient amplitude. Recruitment of SR release units, based on the latency of single $\mathrm{I}_{\mathrm{Ca}}$ channels, may be responsible for the dependence of the $\mathrm{Ca}^{2+}$ transient on pulse duration (11). In this study, we show for the first time that in infant human atrial cells, the $\mathrm{Ca}^{2+}$ transient amplitude depends on the duration of the membrane depolarization. Further experiments are required to determine whether the mechanism of this relationship is similar to that found in ventricular cells of other species.

Age-dependent differences in the action potential shape have been shown in isolated cells from several species (12-16), including human atria $(4,5)$. In mouse ventricle $(15,16)$ and rat ventricle $(13,14)$, the neonatal action potential has a slower early repolarization phase and more pronounced early plateau. Similar age-dependent differences have been demonstrated in the human atria from intact atrial strips (5) and from isolated cells (4). Escande et al. (5) did microelectrode recordings from adult $\left(30-67\right.$ y) or infant $(2-22 \mathrm{mo})$ atrial strips at $35^{\circ} \mathrm{C}$, showing that adult tissue had a significantly faster early repolarization, with a low "plateau" level. The time for $90 \%$ repolarization $\left(\mathrm{APD}_{90}\right)$ was $494 \mathrm{~ms}$ for adult tissue versus 270 $\mathrm{ms}$ for infant tissue. More recent work on human adult atrial strips and isolated atrial cells by Dobrev et al. (17) showed $\mathrm{APD}_{90}$ from adult atrial strips to be $207 \mathrm{~ms}$, whereas $\mathrm{APD}_{90}$ of isolated adult atrial cells was $202 \mathrm{~ms}$. Both the intact adult tissue and the isolated adult cells had a large, rapid, early repolarization, with the time for $20 \%$ repolarization being only $7 \mathrm{~ms}$ in the intact tissue. The action potentials of these adult cells and from the intact tissue showed little or no plateau, with a fast partial repolarization followed by a slower phase of repolarization. Similar values of $\mathrm{APD}_{90}(178-230 \mathrm{~ms}$ over a frequency range of $2-0.1 \mathrm{~Hz}$ ) were obtained from human atrial adult cells by Li et al. (18). These results are similar to our own recently published data (4) on isolated human adult atrial cells in which we measured $\mathrm{APD}_{90}$ of $170 \mathrm{~ms}$ and $\mathrm{APD}_{30}$ of $3.6 \mathrm{~ms}$. When we isolated cells from human infant atria ( $<1 \mathrm{y}$ of age), we obtained $\mathrm{APD}_{90}$ of $179 \mathrm{~ms}$ and $\mathrm{APD}_{30}$ of $24 \mathrm{~ms}$. The action potentials that we recorded from infant atrial cells and used in the present study are different from what we recorded in adult atrial cells, and these changes are qualitatively similar to those reported by Escande et al. (5)

The effects of changes in the action potential waveform on the amplitude of $\mathrm{I}_{\mathrm{Ca}}$ and the $\mathrm{Ca}^{2+}$ transient have been most clearly shown by using the technique of applying recorded action potentials as voltage waveforms to which the cell is "voltage clamped." We previously used guinea pig ventricular myocytes and produced either a normal action potential waveform or a waveform with accelerated early repolarization at physiologic temperature and showed that a more rapid repolarization produced a greater amplitude of $\mathrm{I}_{\mathrm{Ca}}(1)$ and also a larger $\mathrm{Ca}^{2+}$ transient (2). Sah et al. (3) showed that applying ramp repolarizations of varying slope to rat ventricular cells (at room temperature) produced greater calcium transients with faster repolarization as a result of increased $\mathrm{I}_{\mathrm{Ca}}$. In contrast, for cells from animals (e.g. rodents) with action potentials that have a very fast early repolarization in both ventricular and atrial tissue, slowing the repolarization rate results in greater calcium transients. Sah et al. (19) recorded action potentials from cells that were isolated either from normal or from infarcted rat ventricle. They then applied these action potentials (with voltage clamp) to cells that were isolated from normal rat ventricle and showed that the "infarct" action potential, which had a slowed early repolarization, resulted in a larger $\mathrm{Ca}^{2+}$ transient and greater cell shortening than the "normal" action potential. The $\mathrm{I}_{\mathrm{Ca}}$ recorded during the "normal" action potential was larger in amplitude but shorter in duration than the $\mathrm{I}_{\mathrm{Ca}}$ recorded during the "infarct" action potential, because the very fast repolarization of the "normal" action potential deactivated the calcium conductance. Thus, the time integral of $\mathrm{I}_{\mathrm{Ca}}$ was larger for the "infarct" action potential. Subsequently, they showed that the $\mathrm{Ca}^{2+}$ transient had a biphasic response to ramp waveforms with varying repolarization slope (20). For ramps with durations shorter than $50 \mathrm{~ms}$, increasing the ramp duration (thereby slowing the rate of repolarization) increased the $\mathrm{Ca}^{2+}$ transient, but as the ramp duration increased to $>50 \mathrm{~ms}$, the $\mathrm{Ca}^{2+}$ transient decreased with increasing ramp durations. The relationship between the repolarization waveform and the calcium transient is clearly complex. The actual time course and amplitude of the $\mathrm{I}_{\mathrm{Ca}}$ depends on the time-varying membrane potential, the time course of L-type calcium channel activation and inactivation (partly produced by the rise in intracellular calcium), and a possibly time-varying equilibrium potential for this current, particularly if the calcium concentration in a subsarcolemmal space increases more rapidly and to higher levels than the average cytoplasmic calcium concentration (21). The time course and amplitude of the intracellular calcium transient also depends on the calcium loading and release of the SR in response to calcium entering via the L-type calcium channels and, to some extent, via the sodium-calcium exchanger (22). Sah et al. (19) showed that changes in the early repolarization rate caused increases in $\mathrm{Ca}^{2+}$ transient primarily through increase in $\mathrm{Ca}^{2+}$ trigger (increase in $\mathrm{Ca}^{2+}$ entry) with a smaller contribution by having an increased SR load. In recent work, Sun et al. (23) showed that increasing late repolarization (by selectively inhibiting $I_{k, \text { slow }}$ ) while not changing the early repolarization phase increased cell shortening and the $\mathrm{Ca}^{2+}$ transient in mouse ventricular cells. They showed that this increase was due to a larger SR load and not due to greater $\mathrm{Ca}^{2+}$ trigger. Note that in the present study, we cannot definitively say which is responsible for the change in $\mathrm{Ca}^{2+}$ transients in infant atrial cells with the different action potential waveforms (see Figs. 3 and 4). Hatem et al. (24) showed that calcium-induced calcium release from the SR as a result of influx of $\mathrm{Ca}^{2+}$ through $\mathrm{I}_{\mathrm{Ca}}$ occurred in infant human atrial cells. Therefore, it is likely that a combination of increased SR load and increased $\mathrm{Ca}^{2+}$ trigger as a result of changes in the early repolarization phase of the infant and adult action potentials is responsible for the change in $\mathrm{Ca}^{2+}$ transients in infant atrial cells with the different action potential waveforms. In our experiments with variable duration voltage-clamp pulses (Fig. 1), there was an equal SR load, and the duration of the pulse 
causes significant changes in the $\mathrm{Ca}^{2+}$ transient. In addition, the sodium-calcium exchanger has been shown to be larger in newborn rabbit ventricle than adults and may act, in ventricular cells, in the reverse mode to bring $\mathrm{Ca}^{2+}$ into the cell during the plateau of the action potential and thus may be able to act as a trigger SR $\mathrm{Ca}^{2+}$ release (25-28). Reverse-mode sodiumcalcium exchanger as a trigger for calcium release has been shown in cardiac myocytes from several species (29-31). Furthermore, sodium-calcium exchanger can be up-regulated in heart failure $(32,33)$ and can provide an additional source of $\mathrm{Ca}^{2+}$, compensating for impaired SR function (34-36). In human ventricle, $\mathrm{Qu}$ et al. (37) showed that both mRNA and protein levels of sodium-calcium exchanger were higher in neonates than in adults. As a result of the prolonged plateau found in infant atrial cells and the possibility that infant atrial cells may have more sodium-calcium exchanger than adult atrial cells, it is possible that reverse-mode sodium-calcium exchanger contributes to the increased $\mathrm{Ca}^{2+}$ transients seen in response to the infant action potential in our experiments (Figs. 3 and 4). An alternative explanation is that the fast repolarization of the adult action potential favors forward-mode sodiumcalcium exchanger so that the abbreviated calcium transient seen with the adult action potential waveform may be due in part to increased calcium extrusion by sodium-calcium exchanger (38). Further experiments are required to determine the role of SR load, of $\mathrm{I}_{\mathrm{Ca}}$ as a trigger for SR release, and of the sodium-calcium exchanger in the increase of the $\mathrm{Ca}^{2+}$ transient seen in response to the prolonged infant action potential in infant atrial cells. None of these relationships has been quantitatively established for human atrial cells at physiologic temperature.

Our measurements of calcium transients at physiologic temperature by high-speed confocal fluorescence microscopy shows considerable differences from previous studies done on human atrial cells at room temperature. Hatem et al. (39) measured $\mathrm{Ca}^{2+}$ transients in voltage-clamped adult human atrial cells at room temperature using fluorescence confocal microscopy and showed very slow, dome-shaped $\mathrm{Ca}^{2+}$ transients. These $\mathrm{Ca}^{2+}$ transients were observed after $\mathrm{I}_{\mathrm{Ca}}$ activation and were caused by SR $\mathrm{Ca}^{2+}$ release. They suggested that the prolonged $\mathrm{Ca}^{2+}$ transients were due to slow $\mathrm{Ca}^{2+}$ release or reduced capacity of $\mathrm{Ca}^{2+}$ uptake by SR. Hatem et al. (24) measured calcium transients and $\mathrm{I}_{\mathrm{Ca}}$ in neonatal human atrial myocytes showing a very slow calcium transient at room temperature that was suppressed by ryanodine and increased by isoproterenol. It is important to note that these transients were measured at room temperature, and the slow rise and slow decay of $\mathrm{Ca}^{2+}$ transients could be due to the low temperature and slow $(0.1 \mathrm{~Hz})$ pacing frequency. The work that we present here was done with a faster recording system and also at physiologic temperature, showing a detectable rise in intracellular calcium within $4 \mathrm{~ms}$ of the upstroke of the action potential and a half-time for the rise in calcium concentration of $\sim 12 \mathrm{~ms}$. The rise time, in our data, was affected by the shape of the early repolarization phase of the action potential, with the rapid repolarization of the adult action potential waveform seeming to "interrupt" the rise in the calcium transient. To our knowledge, there are no previous reports of calcium transients in human atrial cells at physiologic temperature. It is important to note that we are not comparing here the amplitude or time course of calcium transients in adult cells versus calcium transients of infant cells. We are specifically testing the effects of the different action potential waveforms (previously recorded from adult or from infant cells) on the calcium transients of infant cells.

In summary, our results show that the delayed (compared with adult cells) early repolarization of infant cells [which may be produced by a faster inactivating transient outward current, compared with adult cells (4)] alters the $\mathrm{Ca}^{2+}$ transient in these cells, which may compensate for the lower availability of basal calcium current in infant cells (6). The steep relationship that we have demonstrated between test-pulse duration and the calcium transient suggests that modulation of the early repolarization phase of the action potential may be of great significance in modulating excitation-contraction coupling.

\section{REFERENCES}

1. Kumar R, Joyner RW 1995 Calcium currents of ventricular cell pairs during action potential conduction. Am J Physiol 268:H2476-H2486

2. Wagner MB, Wang YG, Kumar R, Golod DA, Goolsby WN, Joyner RW 2000 Measurements of calcium transients in ventricular cells during discontinuous action potential conduction. Am J Physiol 278:H444-H451

3. Sah R, Ramirez RJ, Backx PH 2002 Modulation of $\mathrm{Ca}(2+)$ release in cardiac myocytes by changes in repolarization rate: role of phase- 1 action potential repolarization in excitation-contraction coupling. Circ Res 90:165-173

4. Wang Y, Xu H, Kumar R, Tipparaju SM, Wagner MB, Joyner RW 2003 Differences in transient outward current properties between neonatal and adult human atrial myocytes. J Mol Cell Cardiol 35:1083-1092

5. Escande D, Loisance D, Planche C, Coraboeuf E 1985 Age-related changes of action potential plateau shape in isolated human atrial fibers. Am J Physiol 249:H843-H850

6. Tipparaju SM, Kumar R, Wang Y, Joyner RW, Wagner MB 2004 Developmental differences in L-type calcium current of human atrial myocytes. Am J Physiol 286:H1963-H1969

7. Bers DM, Lederer WJ, Berlin JR 1990 Intracellular Ca transients in rat cardiac myocytes: role of Na-Ca exchange in excitation-contraction coupling. Am J Physiol 258:C944-C954

8. Cannell MB, Berlin JR, Lederer WJ 1987 Effect of membrane potential changes on the calcium transient in single rat cardiac muscle cells. Science 238:1419-1423

9. Cleemann L, Morad M 1991 Role of Ca2 + channel in cardiac excitation-contraction coupling in the rat: evidence from $\mathrm{Ca} 2+$ transients and contraction. J Physiol 432:283-312

10. Isenberg $\mathrm{G}$, Han $\mathrm{S} 1994$ Gradation of $\mathrm{Ca}(2+)$-induced $\mathrm{Ca} 2+$ release by voltage-clamp pulse duration in potentiated guinea-pig ventricular myocytes. J Physiol 480:423-438

11. Bers DM 2001 Excitation-contraction coupling. In: Excitation-Contraction Coupling and Cardiac Contractile Force. Kluwer Academic Publishers, Dordrecht, pp 203-244

12. Kato Y, Masumiya H, Agata N, Tanaka H, Shigenobu K 1996 Developmental changes in action potential and membrane currents in fetal, neonatal and adult guinea-pig ventricular myocytes. J Mol Cell Cardiol 28:1515-1522

13. Kilborn MJ, Fedida D 1990 A study of the developmental changes in outward currents of rat ventricular myocytes. J Physiol (Lond) 430:37-60

14. Sartiani L, Cerbai E, Lonardo G, DePaoli P, Tattoli M, Cagiano R, Carratu MR, Cuomo V, Mugelli A 2004 Prenatal exposure to carbon monoxide affects postnatal cellular electrophysiological maturation of the rat heart: a potential substrate for arrhythmogenesis in infancy. Circulation 109:419-423

15. Tanaka H, Sekine T, Nishimaru K, Shigenobu K 1998 Role of sarcoplasmic reticulum in myocardial contraction of neonatal and adult mice. Comp Biochem Physiol A Mol Integr Physiol 120:431-438

16. Wang L, Duff HJ 1997 Developmental changes in transient outward current in mouse ventricle. Circ Res 81:120-127

17. Dobrev D, Graf E, Wettwer E, Himmel HM, Hala O, Doerfel C, Christ T, Schuler S, Ravens U 2001 Molecular basis of downregulation of G-protein-coupled inward rectifying $\mathrm{K}(+)$ current $(\mathrm{I}(\mathrm{K}, \mathrm{ACh})$ in chronic human atrial fibrillation: decrease in GIRK4 mRNA correlates with reduced $\mathrm{I}(\mathrm{K}, \mathrm{ACh})$ and muscarinic receptor-mediated shortening of action potentials. Circulation 104:2551-2557

18. Li GR, Nattel S 1997 Properties of human atrial $\mathrm{I}_{\mathrm{Ca}}$ at physiological temperatures and relevance to action potential. Am J Physiol 272:H227-H235

19. Sah R, Ramirez RJ, Kaprielian R, Backx PH 2001 Alterations in action potential profile enhance excitation-contraction coupling in rat cardiac myocytes. J Physiol 533:201-214

20. Sah R, Ramirez RJ, Oudit GY, Gidrewicz D, Trivieri MG, Zobel C, Backx PH 2003 Regulation of cardiac excitation-contraction coupling by action potential repolarization: role of the transient outward potassium current (I(to)). J Physiol 546:5-18

21. Bers DM 2002 Cardiac excitation-contraction coupling. Nature 415:198-205 
22. Bers DM 2002 Sarcoplasmic reticulum Ca release in intact ventricular myocytes. Front Biosci 7:d1697-d1711

23. Sun H, Oudit GY, Ramirez RJ, Costantini D, Backx PH 2004 The phosphoinositide 3-kinase inhibitor LY294002 enhances cardiac myocyte contractility via a direct inhibition of I(k,slow) currents. Cardiovasc Res 62:509-520

24. Hatem SN, Sweeten T, Vetter V, Morad M 1995 Evidence for presence of Ca2+ channel-gated $\mathrm{Ca} 2+$ stores in neonatal human atrial myocytes. Am J Physiol 268:H1195-H1201

25. Chin TK, Christiansen GA, Caldwell JG, Throrburn J 1997 Contribution of sodiumcalcium exchanger to contractions in immature rabbit ventricular myocytes. Pediatr Res 41:480-485

26. Haddock PS, Coetzee WA, Artman M $1997 \mathrm{Na}+/ \mathrm{Ca} 2+$ exchange current and contractions measured under $\mathrm{Cl}(-)$-free conditions in developing rabbit hearts. Am J Physiol 273:H837-H846

27. Haddock PS, Coetzee WA, Cho E, Porter L, Katoh H, Bers DM, Jafri MS, Artman M 1999 Subcellular $[\mathrm{Ca} 2+]$ i gradients during excitation-contraction coupling in newborn rabbit ventricular myocytes. Circ Res 85:415-427

28. Wetzel GT, Chen F, Klitzner TS $1995 \mathrm{Na}+/ \mathrm{Ca} 2+$ exchange and cell contraction in isolated neonatal and adult rabbit cardiac myocytes. Am J Physiol 268(suppl 2):H1723-H1733

29. Hove-Madsen L, Llach A, Tibbits GF, Tort L 2003 Triggering of sarcoplasmic reticulum $\mathrm{Ca} 2+$ release and contraction by reverse mode $\mathrm{Na}+/ \mathrm{Ca} 2+$ exchange in trout atrial myocytes. Am J Physiol 284:R1330-R1339

30. Litwin SE, Li J, Bridge JH $1998 \mathrm{Na}-\mathrm{Ca}$ exchange and the trigger for sarcoplasmic reticulum Ca release: studies in adult rabbit ventricular myocytes. Biophys J 75:359_ 371

31. Sipido KR, Maes M, Van de Werf F 1997 Low efficiency of Ca2+ entry through the $\mathrm{Na}(+)-\mathrm{Ca} 2+$ exchanger as trigger for $\mathrm{Ca} 2+$ release from the sarcoplasmic reticulum.
A comparison between L-type $\mathrm{Ca} 2+$ current and reverse-mode $\mathrm{Na}(+)-\mathrm{Ca} 2+$ exchange. Circ Res 81:1034-1044

32. Pogwizd SM, Qi M, Yuan W, Samarel AM, Bers DM 1999 Upregulation of $\mathrm{Na}(+) / \mathrm{Ca}(2+)$ exchanger expression and function in an arrhythmogenic rabbit model of heart failure. Circ Res 85:1009-1019

33. Studer R, Reinecke H, Bilger J, Eschenhagen T, Bohm M, Hasenfuss G, Just H, Holtz J, Drexler H 1994 Gene expression of the cardiac $\mathrm{Na}(+)-\mathrm{Ca} 2+$ exchanger in end-stage human heart failure. Circ Res 75:443-453

34. Armoundas AA, Hobai IA, Tomaselli GF, Winslow RL, O'Rourke B 2003 Role of sodium-calcium exchanger in modulating the action potential of ventricular myocytes from normal and failing hearts. Circ Res 93:46-53

35. Dipla K, Mattiello JA, Margulies KB, Jeevanandam V, Houser SR 1999 The sarcoplasmic reticulum and the $\mathrm{Na}+/ \mathrm{Ca} 2+$ exchanger both contribute to the $\mathrm{Ca} 2+$ transient of failing human ventricular myocytes. Circ Res 84:435-444

36. Flesch M, Schwinger RH, Schiffer F, Frank K, Sudkamp M, Kuhn-Regnier F, Arnold G, Bohm M 1996 Evidence for functional relevance of an enhanced expression of the $\mathrm{Na}(+)-\mathrm{Ca} 2+$ exchanger in failing human myocardium. Circulation 94:992-1002

37. Qu Y, Ghatpande A, el-Sherif N, Boutjdir M 2000 Gene expression of $\mathrm{Na}+/ \mathrm{Ca} 2+$ exchanger during development in human heart. Cardiovasc Res 45:866-873

38. Bers DM 2001 Control of cardiac contraction by SR and sarcolemmal Ca fluxes. In: Excitation-Contraction Coupling and Cardiac Contractile Force. Kluwer Academic Publishers, Dordrecht, pp 245-272

39. Hatem SN, Benardeau A, Rucker-Martin C, Marty I, de Chamisso P, Villaz M, Mercadier JJ 1997 Different compartments of sarcoplasmic reticulum participate in the excitation-contraction coupling process in human atrial myocytes. Circ Res 80:345-353 